\title{
EXPLORING AFRICAN UNION LAW THROUGH THE LENSES OF COMPARATIVE LAW: A COMPARATIVE ANALYSIS WITH EUROPEAN UNION LAW
}

Dr Olufemi Amao \& Dr Matthew Chidebe Nwankwo ${ }^{1}$

\section{INTRODUCTION}

As international law continues to expand, international organizations inevitably morph into diverse and complex entities that challenge the traditional understanding of their natural status. The long-established understanding that international law primarily depends on relations between states is obsolete in the face of new global realities. The discipline now focuses on the place and rights of individuals within the international system, the organization of states into regional organizations, and how the latter affects the collective interest of the international community. In this vein, the European Union (EU) is often viewed as a manifestation of the transformation of international law and is popularly recognized as the archetypal success story for the constitutional ordering of states beyond the municipal level. However, the continued expansion of the EU has brought specific challenges, particularly on the most effective approach to studying its institutions within international law scholarship. The transformation of the EU occasioned by increased codification, harmonization and convergence, as part of the integration process, has led scholars to identify a methodological conundrum. They argue that comparative law, though once useful, has diminished its relevance as a tool to improving the understanding of the EU. ${ }^{2}$

In addition, recent events such as Brexit arguably warrant even closer examination into the current methods of scrutinizing the EU and its position as a model organization. Brexit has been said to imply a constitutional transformation in the shape and balance of the EU and could represent a 'tipping point' for the EU. ${ }^{3}$ The present stature of the EU warrants its treatment as a constantly evolving institution deserving of new heuristic techniques. While stakeholders within

\footnotetext{
${ }^{1}$ Dr Olufemi Amao is a Reader at the Sussex Law School University of Sussex, UK and he is the PI for the AHRC funded African Union Law Research Project. Dr Matthew Chidebe Nwankwo is a Senior Lecturer at the Faculty of Law, University of Nigeria.

2 See M. Siems, 'The End of Comparative Law' (2007) 2 Journal of Comparative Law, 133-150.

${ }^{3}$ N.C Rodrigues, 'Brexit and the Future of the EU: Move Back or Forward' in N.C Cabral, J.R Goncalves, N.C Rodrigues (eds), After Brexit: Consequences for the European Union (Palgrave Macmillan, 2017), 67-68.
} 
the EU are battling with ideas to better understand the organization, ${ }^{4}$ its trajectory poses several challenges for other regional organizations that have been inspired by the EU. Regional organizations such as the African Union (AU), which is still undergoing its evolutionary process, are ideally studied side by the side with the EU, albeit within an autochthonous context, to draw lessons that may be beneficial to its long-term success. Currently, the institutional make-up of the AU, the African Economic Community (AEC), and the relational issues governing the AU and the Regional Economic Communities (REC) has created an expanding legal order deserving of its own distinct field of scholarship, and perhaps in need of identifiable methodological approaches. ${ }^{5}$

Comparison between regional organizations, in this case, between the EU and the AU may require a new approach. Comparisons may have to adopt a combination of theories upon which each organization was founded. ${ }^{6}$ A second layer of the comparative exercise may scrutinize the norms and institutions of both organizations as distinct legal systems. This chapter will attempt a comparative analysis of the two different regional organizations with similar objectives but different capabilities. It will mainly adopt the later approach which is to take a

\footnotetext{
${ }^{4}$ The Brexit conundrum has propelled the EU to wake up to the possibility of disintegration and the need to engage in urgent reforms regarding both its economic and monetary arm and its political and geo-strategic role. In 2017 the European Commission President released a white paper titled 'White Paper on the Future of Europe' detailing the five scenarios for the reform of the EU by 2025. The white paper lists five scenarios for EU reforms namely; (i) Carrying on; (ii) Nothing but the single market; (iii) Those who want to do more; (iv) Doing less more efficiently; (v) Doing much more together. See 'White Paper on the Future of Europe' at https://ec.europa.eu/commission/publications/white-paper-future-europe_en. For analysis of the scenarios for EU reforms see generally, N.C Cabral et al (note 3 above).

${ }^{5}$ Writing extensively on the legal framework for managing relational issues of regional integration in Africa see RF Oppong, Legal Aspects of Economic Integration in Africa (Cambridge University Press, 2011), 30 - 63. See also 0. Amao, African union law: the emergence of a sui generis legal order (Routledge, 2018).

${ }^{6}$ The AU and its predecessor the OAU were founded on the idea of Pan-Africanism. See generally Amao (supra), chapter 2. Pan-Africanism has defied any generally accepted definition. Legum refers to the concept as a 'movement of ideas and emotions'. At best, Pan-Africanism is a multi-dimensional concept, which culturally refers to the 'common ancestry' of African people and politically as a means to encourage the unification of African states. See C. Legum, Pan Africanism; A short political guide, (London: Pall Mall Press, 1962), 14; F. Viljoen, International Human Rights in Africa, $2^{\text {nd }}$ Edition (Oxford: Oxford University Press 2007), 157- 158. On the part of the EU, theories of European integration attempt to explain the political dynamics of European Integration and the nature of the EU political system. Theories of European integration range from Neo-functionalism to liberal intergovernmentalism (LI) and more recently multi-level governance (MLG). While there are several theories of European integration, none have fully explained the process of EU integration although each seems to partially explain aspects of the EU process. See, D. Anderson, 'D. Mitrany (1888-1975): An Appreciation of His Life and Work' (1998) 24 RIS, 579; L. Lindberg, The Political Dynamics of European Economic Integration, (CA: Stanford University Press, 1963); S. Hoffman, The European Sisyphus: Essays on Europe 1964-1994, (Oxford: Westview Press, 1995); A. Moravcsik, The Choice for Europe: Social Purpose and State Power from Messina to Maastricht, (London: UCL Press, 1998); B.Rosamond, 'New Theories of European Integration', in M. Cini and N. Perez-Solorzano Borragan (eds), European Union Politics, $3^{\text {rd }}$ Edition (Oxford: OUP, 2010).
} 
look at the norms and institutions emanating from both organizations. The following sections have the main objective of contributing to the debate on comparative analysis of international organizations using the EU and the AU as its central focus. The chapter is organized in the following format; the first part of the chapter briefly discusses the problem of methodology in international legal argumentation. The second part looks at the role of comparative law in providing an understanding of the EU. The third part compares the organizational nature of the AU and the EU. The fourth part recommends ways to develop AU law. The final part concludes.

\section{COMPARATIVE LAW AND MODERN METHODS OF INTERNATIONAL LEGAL ARGUMENTATION}

Comparative legal analysis is essential and central to international law scholarship and debate. It refers to a system of analyzing different fields and it serves as a major source of legal discourse on practical issues of law. Comparative analysis has been instrumental in the development of legal research in recent years due to its "potential for sharpening, deepening and expanding the lenses through which" the law can be perceived. ${ }^{7}$ It is both a method of analysis and a substantive field in its own right. According to Reimann, it is related to three key areas: foreign law, legal families, and the process of comparison itself. ${ }^{8}$ It has been referred to as a technique, a perspective, or a (systematic or empirical) science. ${ }^{9}$

Comparative legal analysis introduces new legal concepts, styles, organizations and categorizations thereby opening unsuspected possibilities in the very notion of the law. ${ }^{10}$ Historically, comparative law had a Eurocentric origin but its usage has become universal as an analytical method. ${ }^{11}$ Originally based on comparison of legal cultures and legal traditions, comparative law has become much more although questions remain over whether the method for which comparative law is purely known has delivered any substantial knowledge in post-modern times.

\footnotetext{
${ }^{7}$ V. Grosswald Curran, 'Dealing in Difference: Comparative Law's Potential for Broadening Legal Perspectives' (1998) 46 American Journal of Comparative Law, 647.

${ }^{8}$ M. Reimann, 'The Progress and Failure of Comparative Law in the Second Half of the Twentieth Century' (2002) 50 American Journal of Comparative Law 671, 673.

${ }^{9}$ Idem, 683.

${ }^{10}$ Curran, note 7 above.

${ }^{11}$ Rene David's Scheme and Zweitgert and Kotz' initial definition of legal families according to style were first published in the 60s. R David ,Les Grands Systemes de Droit Contemporains' (1964); K. Zweigert \& Hein Kötz, Einführung in die Rechtsvergleichung I (1969), 67-80.
} 
Beyond its usage as a method for analytical exercises, comparative law has been met with criticism over its suitability to be considered a discipline. While it may have delivered in creating a cache of knowledge on legal systems and traditions the world over, as a field of inquiry, comparative law may have struggled. It is suggested that the discipline has rarely the capacity to generate "broad and deep insight of general interest e.g. into the structure and development of legal systems or into the relationship between law, society and culture on a regional or worldwide basis". ${ }^{12}$ Consequently, it has somewhat suffered from a lack of academic recognition expected in an international age, ${ }^{13}$ although this may be slowly changing given this realisation by comparatists. $^{14}$

Perhaps one of the most scathing criticisms of comparative law as a discipline is the clinging on to the orthodox model established by European scholars in its early days. Reimann highlights the prevalence of the "Country and Western tradition" 15 in comparative law and alludes to the fact that the main focus on "nation state legal systems of Western capitalists societies, its obsession with common-civil law dichotomy, and its preoccupation with private law rules and doctrines, [...] is now in dire need of a major overhaul'. ${ }^{16}$ Criticisms of this nature call into focus the need to reimagine how comparative law is assessed and applied. Comparative law is many things if creatively applied. In order to present real answers emphasis may be placed on other imaginable approaches that exist outside previously laid down methods. ${ }^{17}$

In due course, comparative scholars and practitioners may wonder what approach to adopt in comparing international organizations which are complex-issue institutions housing various legal systems. How can the African Union (AU) as an organization compare with the European Union (EU)? In the process of comparing, what standards should the international law scholar adopt to provide answers? Is an interdisciplinary approach the best? These questions and more plague the mind of a comparative scholar particularly in the relatively nascent area of AU Law. The comparison of an emerging body of laws under the umbrella of the AU with the

\footnotetext{
${ }^{12}$ Reimann (note 8 above), 685.

${ }^{13}$ For these criticisms see, P. Legrand, 'European Legal Systems are not Converging' (1996) 45 International and Comparative Law Quarterly, 52.

${ }^{14}$ Writing on the need to understand Comparative Law as a normative science see, J. Bell, 'Legal Research and the Distinctiveness of Comparative Law' in M. Van Hoeke (ed), Methodologies of Legal Research, (Hart Publishing, 2011), $156-175$.

${ }^{15}$ W. Twining, Globalization and Legal Theory (Cambridge University Press 2000), 184.

${ }^{16}$ note 12 above.

17 Bell argues that while comparative law is a mainly a hermeneutical exercise it is also institutional and interpretative, and it is these criteria that make it a normative social science. See Bell, (note 14 above) 161 - 167.
} 
archetypal supranational entity as the EU is bound to present methodological challenges. However, exercises of this nature must be attempted to lay the foundations for further research in the future. Experimentation in international law is under-utilized due to the over-reliance of the international lawyer on "legalism" 18 and "legal formants"19 or the failure to admit to the constant flux of methodological and theoretical perspectives.

Slowly, the confinement of international law scholarship to the traditional methods of research is beginning to change due to the need to deliver more relevant and accurate results. For instance, an increasing number of experimental research are now exploring the causal mechanism through which international law could impact behaviour. ${ }^{20}$. Originally a strategy utilised by political scientists, international lawyers are beginning to adopt experimental research to query the varied causal mechanisms through which international law may lead to certain behavioural outcomes. ${ }^{21}$ This emerging technique, albeit less than two decades old, holds huge potentials for moving international law scholarship beyond the current logjam of methodological confusion. Furthermore, it is encouraging that scholars realise the problems in the current methodologies and are willing to adopt methods that are considered exclusive to other fields to the shaping of international law for concrete and more reliable theories. Along this line, the following sections of this chapter will attempt a dynamic contribution to comparison between EU law, which is substantially developed, ${ }^{22}$ and the emergent AU Law.

\footnotetext{
18 Richard Posner has criticized the lawyer for "lawyer's hubris". He argues that lawyers are overly dependent on their legalistic background to solving international problems. See, R. Posner, Law, Pragmatism and Democracy (Harvard University Press 2003), 308- 309.

${ }^{19}$ On the importance of legal formants in international legal argumentation see J.Bell, 'The Argumentative Status of Foreign Legal Arguments' (2012) 8 Utrecht Law Review 8.

20 J.L Dunoff \& M. A Pollack, 'Experimenting with International Law' (2017) 28 European Journal of International Law, 1317

${ }^{21}$ See J.L Dunoff \& M. A Pollack, 'Experimenting with International Law' (2017) 28 European Journal of International Law, 1317; Shereshevsky and Noah, 'Does Exposure to Preparatory Work Affect Treaty Interpretation? An Experimental Study on International Law Students and Experts', (2017) 28 European Journal of International Law 1287; Puig and Strezzhnev, 'The David Effect and ISDS' (2017) 28 European Journal of International Law 731.

${ }^{22}$ The story of the EU has undergone various stages of formal and organizational reforms. It starts off with the original 1951 European Coal and Steel Community Treaty, followed by the European Economic Community (EEC) and Euratom treaties of 1957. After this the organization transformed into the Maastricht treaty regime in 1986, the Amsterdam and Nice treaties before the last stop at the Lisbon Treaty.
} 


\section{EU LAW AS A HOLDING HOUSE FOR COMPARATIVE LAW: LESSONS FOR THE AU?}

Designs of international organizations range from highly complex to loose with continued expansion into numerous organizational set ups. ${ }^{23}$ The EU is an organization of interest globally for the reason that its institutional practice is robust and well publicised. It also boasts a court system that can shed light on arising legal questions. ${ }^{24}$ The robustness of EU institutions makes it a fertile ground for comparative law. ${ }^{25}$ In fact, comparative law has been instrumental in the early years of construction of the European Communities and their progression into the Union that it is today. Comprehensive comparative studies have helped produce a European legal order with the attribute of legal harmonization in constantly expanding spheres of economic and political integration. ${ }^{26}$

In terms of practical application of comparative law in EU law, three main patterns of application may be discerned. First, comparative law has acted as the tool through which different national legal traditions have been combined for the development of substantive law as well as institutional principles on which the union rests. ${ }^{27}$ For example, the French administrative tradition has been credited for shaping not only the text of the European treaties, but also the structure and style of its institutions, particularly the Court of Justice for the European Union (CJEU) and its abstract, impersonal and deductive philosophy. ${ }^{28}$ The accession of the UK and Ireland to the European Community birthed the common law approach in the interpretation of cases and an emphasis on procedure and the procedural rights of parties. ${ }^{29}$

\footnotetext{
${ }^{23}$ See generally B. Koremenos, C. Lipson, and D. Snidal, The Rational Design of International Institutions (Cambridge University Press, 2004).

24J. Klabbers, 'Transforming Institutions: Autonomous International Organizations in Institutional Theory' (2017) 6 Cambridge International Law Journal 105, 113.

${ }^{25} \mathrm{EU}$ institutions like the Commission and the Court are natural laboratories of comparative law, bringing experience from different legal traditions into a creative melting pot of legal exchange and experimentation. See $A$. B. Engelbrekt, 'Comparative Law and European Law: the End of an Era, a New Beginning, or Time to Face the Methodological Challenges', (2015) 61 Scandinavian Studies in Law, 88.

${ }^{26}$ See R. Van Gestel and H. Micklitz, 'Comparative Law and EU Legislation: Inspiration, Evaluation or Justification?, in M. Adams \& D. Heirbaut (eds.) The Method and Culture of Comparative Law, (Oxford: Hard Publishing 2014), 301-3017.

${ }^{27}$ Engelbrekt (note 25 above), 91.

${ }^{28}$ See T. Koopmans, 'The Birth of European Law at the Crossroad of Legal Traditions', (1991) 39 American Journal of Comparative Law, 493; N. Fennely, 'Legal Interpretation at the Court of Justice' (1996/7) 20 Fordham International Law Journal 656, 671.

${ }^{29}$ See Rodrigues, note 3 above, 68.
} 
In addition, comparative law has been evidently applied in the myriad of projects of approximation and harmonization of areas of law and regulation that eventually formed the bulwark of the legislative acquis. In this wise, the extent of comparative analyses depends on a variety of factors such as the area of law and policy concerned, the type of harmonization undertaken (minimum, maximum, full or partial) and the form of the legislative act under preparation. ${ }^{30}$ For instance, in the early days of the EU competition law in the 1960s, an academic study was conducted at the Max Planck Institute for Foreign and International Patent, Copyright and Competition Law in Munich under the leadership of its Director Professor Ulmer. $^{31}$

Third, and probably the most obvious use of comparative law in the work of the EU, is the particular methodology developed by the Court of Justice of the European Union (CJEU) and applied in its mandate to ensure the proper interpretation of EU law. The court's method of adopting comparative law is best understood in its triangular teleological interpretation and gapfilling function of general principles has been called an "evaluative" one. ${ }^{32}$ For the Community courts comparative law stands distinctly as one method amongst other methods of interpretation of the law (such as literal, exegetic, historical, systematic interpretation) and it is recognized as a viable tool for establishing binding EU law. ${ }^{33}$

The reliance on comparative law in the EU judicature is a natural manifestation for a number of reasons. First, the members of the Community courts have their roots in different legal cultures, the texts and notions to be interpreted are mostly multilingual, and majority of the cases brought before the Community judicature precisely emanate from within national context. ${ }^{34}$ For example, in one of the earlier cases of the European Court of Justice (ECJ) - The

\footnotetext{
${ }^{30}$ Engelbrekt (note 26 above), 92.

${ }^{31}$ See E. Ulmer, ,Das Recht des Unlauteren Wettbewerbs' in den Mitgliedstaaten der EWG. Band I.

VergleichendeDarstellung (Munchen: Beck, 1965). The study initially resulted in six volumes covering all relevant aspects of law of this area of law in the six founding member states of the European communities. New volumes were added to cover the accession of the UK, Ireland and Denmark several years later and subsequent studies were undertaken with the continued accession of member states.

${ }^{32} \mathrm{X}$. Groussot, General Principles of Community Law, (Groningen: Europa Law Publishing 2006), 17.

${ }^{33} \mathrm{~K}$. Lenaerts, 'Interlocking Legal Orders in the European Union and Comparative Law', (2003) 52 International and Comparative Law 873. See also N. Fennelly, 'Legal Interpretation at the European Court of Justice', (1996) 20 Fordham International Law Journal, 656.

${ }^{34}$ Ibid., 875. See also, G. Van Calster, 'The EU's Tower of Babel - The Interpretation by the European Court of Justice of Equally Authentic Texts Drafted in more than one Official Language', (1997) Yearbook of European Law, pp. 363 -93.
} 
Alegra $^{35}$, the approach of the court illustrates this point. Each applicant in these staff cases sought to obtain the annulment of a decision of the Common Assembly which had withdrawn his or her appointment as an official on the ground that the appointments had been made illegally. The court found that the treaty in existence at the time did not lay down the conditions upon which an institution of the Community can lawfully set aside an administrative measure, which was invalidly adopted. The Court of Justice determined that to solve the problem presented by the parties, it must resort to the 'rules acknowledged by the legislation, the learned writing and the case law of the member countries'. ${ }^{36}$ After comparative study of the legal traditions of the six Member States, the Court 'accept[ed] the principle of the revocability of illegal measures at least within a reasonable period of time., 37

Also instructive, are the legal provisions that create room for the application of comparative law. Article 19(1) Treaty of the EU (TEU) ${ }^{38}$ provides that the main task of the European Court of Justice (ECJ) and the General Court $(\mathrm{GC})^{39}$ is to ensure that in the interpretation and application of the Treaties the law is observed' 40 is often cited as the primary source of legitimation for EU recourse to comparative law. The court once emphatically leveraged this provision as the basis of its comparative law approach when it stated that in pursuance of the task conferred on it by article 220 of the EC Treaty with regard to the interpretation and application of the Treaty, the law is observed, '[...] in accordance with the generally accepted methods of interpretation, in particular by reference to the fundamental principles of the EU legal system and, where necessary, general principles common to the legal principles of Member States. ${ }^{41}$ Comparative law under the EU can thus be viewed as a manifestation of legal traditions, written and unwritten, shared by Member States upon which the

35 Joined Cases 7/56 and 3/57 to 7/57, Alegra and Others v Common Assembly [1957] ECR 39.

${ }^{36}$ Ibid, 55.

${ }^{37}$ Ibid, 56.

${ }^{38}$ Consolidated version of the Treaty on European Union, 13 December 2007, 2008/C 115/01.

${ }^{39}$ Under the Treaty of Lisbon (ToL) all the EU courts are referred to as the "Court of Justice of the European Union". This collective name covers three courts namely the CJEU which was previously known as the Court of Justice of the European Communities and is colloquially known as the European Court of Justice; the General Court (GC), which was previously known as the Court of First Instance (CFI); and specialised courts which were previously known as "judicial panels". See A. Kaczorowska-Ireland, European Union Law, $4^{\text {th }}$ Edition (Routledge, 2016$), 95$.

${ }^{40}$ Article 19(3) of the TEU states that the CJEU shall:

(a) rule on actions brought by a Member State, an institution or a natural or legal person;

(b) give preliminary rulings, at the request of courts or tribunals of the Member States, on the interpretation of Union law or the validity of acts adopted by the institutions;

(c) rule in other cases provided for in the Treaties.

${ }^{41}$ Joined Cases C-46/93 and C-48/93, Brassiere du Pecheur and Factortame [1996] ECR 1-1029, para 27. 
EU judicature arrives at the ius commune or common law upon which the treaty is to be interpreted and applied.

The comparative law method is also grounded in the combined provisions of Articles $6(2)$ and 46 of the Treaty of the European Union (TFEU) which gives the ECJ jurisdiction within limits, to protect and ensure that fundamental rights as they emanate from constitutional traditions common to member States as general principles of community law. These provisions are central to the successful creation of a community legal system, not merely because they encourage the courts to factor in legal traditions of Member States, but also admittance that national laws may be better equipped to plug gaps existing in EU law.

One area where the application of comparative law through AU institutions presents problems is, the diversity of legal traditions at various levels of the region. This mix of competing legal systems creates problems over efforts to create a harmonized regional legal order. Diversity of laws in Africa is manifest in three major ways; first, there is internal diversity within the individual countries. Second, there is diversity among different African countries (mainly Francophone, Anglophone, Lusophone, and Islamic legal systems all competing) and third, there is diversity between African states and other (non-African) states. ${ }^{42}$ At the institutional level of the AU, it is unclear if certain member states have influenced aspects of AU law or whether the AU has deliberately attempted to balance these competing legal traditions through its organs. ${ }^{43}$

In comparison to the EU instruments establishing most regional courts in Africa make scanty reference to the subject of laws that are applicable, neither do they prescribe the sources

\footnotetext{
${ }^{42}$ G. Bamodu, 'Transnational Law, Unification and Harmonisation of International Commercial Law in Africa', (1994) 32 Journal of African Law, 125.

${ }^{43} \mathrm{~A}$ vital organ of the AU in this wise is the African Union Commission on International Law (AUCIL). The AUCIL was established under Article 5(2) of the Constitutive Act of the AU is the chief advisory body of the organization in the area of legal research. Under Article 4 of the AUCIL statute, its objectives mainly include; a) codification and progressive development of international law in the African continent with particular attention to the laws of the Union as embodied in the treaties of the Union; b) to propose draft framework agreements, model regulations, formulations and analyses of emerging trends in States' practice to facilitate the codification and progressive development of international I law; c) to assist in the revision of existing treaties, assist in the identification of areas in which new treaties are required and prepare drafts thereof; d) to conduct studies on legal matters of interest to the Union and its Member States; e) and to encourage the teaching, study, publication and dissemination of literature on international law in particular the laws of the Union with a view to promoting acceptance of and respect for the principles of international law, the peaceful resolution of conflicts, respect for the Union and recourse to its Organs, when necessary. See the website of the Commission at https://au.int/aucil.
} 
of AU law. ${ }^{44}$ However, a few provisions of the AU institutions are worthy of mention. For instance, article 31 of the Protocol on the Statute of the African Court of Justice and Human Rights (ACJHR ${ }^{45}$ outlined the applicable law of the court. Article 31 provides:

In carrying out its functions, the Court shall have regard to

a) The Constitutive Act;

b) International treaties, whether general or particular, ratified by the contesting States;

c) International custom, as evidence of a general practice accepted as law;

d) The general principles of law recognised universally or by African States;

e) Subject to the provisions of paragraph 1, of Article 46 of the present Statute, judicial decisions and writings of the most highly qualified publicists of various nations as well as the regulations, directives and decisions of the Union, as subsidiary means for the determination of the rules of law;

f) Any other law relevant to the determination of the case.

Also, references were made in the statute establishing the African Union Commission on International Law (AUCIL) ${ }^{46}$ to 'African Law'. The statute incidentally identified, albeit indirectly and vaguely, certain key sources of AU law. In Article 4, the objectives of the AUCIL are stated as follows:

a) to undertake activities relating to codification and progressive development of international law in the African continent with particular attention to the laws of the Union as embodied in the treaties of the Union, in the decisions of the policy organs of the Union and in African customary international law arising from the practice of Member States;

b) to propose draft framework agreements, model regulations, formulations and analyses of emerging trends in States' practice to facilitate the codification and progressive development of international law;

$[\ldots]$

\footnotetext{
${ }^{44}$ Article 7 of the Protocol of the African Court of Human and Peoples' Rights refers to the sources of Law of the court as 'the provisions of the African Charter on Human and Peoples' Rights and other relevant human rights instruments ratified by the States concerned'.

${ }^{45}$ Protocol on the Statute of the African Court of Justice and Human Rights, adopted 1 July 2008, available at https://au.int/en/treaties/protocol-statute-african-court-justice-and-human-rights.

${ }^{46}$ Statute of the African Union Commission on International Law, adopted 4 February 2009, available at https://au.int/en/treaties/statute-african-union-commission-international-law-aucil.
} 
e) to encourage the teaching, study, publication and dissemination of literature on international law in particular the laws of the Union with a view to promoting acceptance of and respect for the principles of international law, the peaceful resolution of conflicts, respect for the Union and recourse to its organs, when necessary.

Other than these peripheral provisions that make indirect reference to a regional body of laws, other sub-regional courts remain mute on community laws.

Within this context, diversity of laws in Africa has been recognized as a major obstacle to economic development. ${ }^{47}$ This diversity of laws takes shape in different ways internally. First, the indigenous customary laws which applied in African countries prior to colonization still apply, mostly in rural areas, and are by no means uniform in most African states and similarities are discernible. Second, in the aftermath of colonization, laws that were considered alien were superimposed on indigenous laws and operate side by side in modern African states. Finally, most African states operate a federal political structure meaning that different regions of the same country make their own laws in respect of certain matters. ${ }^{48}$ This variety causes undeniable uncertainty over the application of law within the legal corpus of African states.

At the regional level, there remains the conundrum of harmonizing the legal families that spread across African legal landscape. Apart from the English common law and the civil law traditions that dominate the legal systems, the spread of Islam into a considerable portion of Africa introduced Islamic law into large populations in Africa making it widely influential in some African countries. In addition, African states that were colonized by different European powers, operated different legal systems before being amalgamated into one country for political expediency, have a peculiar problem. In such countries, it is not uncommon to find two different types of legal systems operating side by side within the same country. ${ }^{49}$ It is therefore imperative, in view of the above scenario to group contemporary legal systems of African

\footnotetext{
47 See, G. Bamodu, note 42 above; M.Ndulo,' Harmonisation of Trade Laws in Africa, (1993) 42 International and Comparative Law Quarterly,101.

${ }^{48}$ Bamodu, note 42 above, 125.

${ }^{49}$ South Africa for instance operates a mixed legal system which consists of Roman law, indigenous Dutch customary law and procedural aspects of common law. In Cameroon common law and civil law operate side by side.
} 
countries into the common law family, continental European civil law family, and the mixed legal family jurisdictions. ${ }^{50}$

In areas such as international commercial law, diversity of laws among African countries continues to impede the achievement of key integration schemes necessitating calls for unique institutional arrangements to ensure legal integration and harmonization of laws. ${ }^{51}$ It is noteworthy that institutional arrangements such as the Organization for the Harmonization of Business Laws in Africa (OHADA) has taken a lead in this regard by ensuring the creation of a predictable set of laws governing trade transactions in the region. ${ }^{52}$ It is hoped that arrangements such as OHADA compensate for the lacuna affecting regional integration in the region.

In the case of European courts, the comparative approach is considered a method of interpretation of EU law, intrinsically linked to the continuous integration process which characterizes the European construction. ${ }^{53}$ One such effect is the development of the stature of EU courts as the lifelines of the European legal order, sometimes even understood to play the role of 'legislators' by their often policy-defining rulings on integration and human rights. ${ }^{54}$ By using comparative law, the EU judicature has laid the foundation for the interlocking of the extant legal orders in the region.

\footnotetext{
${ }^{50}$ Countries which fall into the civil law family are predominantly francophone countries (former colonies of France and Belgium) such as Togo, Ivory Coast and Benin Republic. Common law countries on the other hand are former territories under the colonial administration of Britain such as Ghana, Nigeria and Kenya.

${ }^{51}$ Bamodu note 42 above, 128 - 132; Ndulo, note 47 above, 101 - 118; see more recently R.F Oppong, 'Legal Harmonisation in African Regional Economic Communities: Progress, Intertia or Regress' in J. Döveling, H.I Majamba, R.F Oppong \& U. Wanitzek (eds) Harmonisation of Laws in the East African Community, (Kenya: Law Africa, 2018), $113-138$.

52 OHADA was established on 17 October 1993 by Member States of the Franc Zone to ensure the harmonisation of business laws towards African integration. Writing on the prospects of OHADA in legal integration in Africa see, A. Mouloul, Understanding the Organization for the Harmonisation of Business Laws in Africa, $2^{\text {nd }}$ Edition (2009, OHADA Secretariat); C.M Dickerson, 'Harmonising Business Laws in Africa', (2006) 44 Columbia Journal of Transnational Law, 18.

${ }^{53}$ G.Benos, 'The Practical Debt of Community Law to Comparative Law', (1984) Revue hellenigue de droit international 251.

${ }^{54}$ Writing on this function of the EU judicature see, F. Wasserfallen, 'The Judiciary as Legislator? How the European Court of Justice shapes Policy-making in the European Union', (2010) 17 Journal of European Public Policy, 1128 1146.
} 


\section{ADVANCING AU LAW IN THE SHADOWS OF EU LAW: ANY POSSIBILITIES?}

The EU's transformation into a supranational organization cannot be understood without groundbreaking decisions of the courts that helped cement the supremacy of EU law. ${ }^{55}$ The European Court of Justice (ECJ) in a series of landmark decisions established three key doctrines that fixed the relationship between Community law and national law. ${ }^{56}$ The application of the principles derived from these decisions popularly placed the EU on the pedestal to becoming the sui generis organization that it is regarded to be today.

The first of the doctrines, the judicial doctrine of direct effect, operates on the presumption that "Community legal norms that are clear, precise, and self-sufficient and must be regarded as the law of the land in the sphere of application of Community law". ${ }^{57}$ Thus, direct effect applies to all actions producing legal effects in the Community. Direct effect operates not only in creating enforceable legal obligations between the Member States and individuals, but also among individuals. ${ }^{58}$ Considered part of national law, EU norms may be relied upon by individuals before their State courts, which are required to provide adequate legal remedies for the EU norms just as if they were enacted by the state legislature. ${ }^{59}$

The doctrine of supremacy is the second principle upon which the EU legal system is built upon. This doctrine is considered a 'constitutionalizing' doctrine when combined with the direct effect. ${ }^{60}$ In its earlier judgments ${ }^{61}$ the ECJ laid down the dictates of the doctrine of supremacy of EU law by stating that in the sphere of application of Community law, any Community norm, be it an article of the Treaty or a regulation enacted by the Commission, supersedes conflicting

\footnotetext{
${ }^{55}$ Van Gend en Loos v. Nederlandse Administratie der Belanstigen (1963) Case 26/62; Flaminio Costa v. ENEL (1964) Case 6/64; Francovich v. Italy (1991) C-6/90.

${ }^{56}$ J. H. H Weiler, 'The Transformation of Europe', (1991) 100 Yale Law Journal, 2403, 2413.

${ }^{57} \mathrm{lbid}$.

${ }^{58}$ See Van Genden Loos ECJ 26/62 [1963] ECR 1 where the ECJ gave private litigants the right to evoke Community law in national courts thereby placing an obligation on member states to protect Community law in national courts.

59 note 56 above.

${ }^{60}$ The constitutionalization of the EU refers to the process by which the Rome Treaty and other Community laws transformed the EU from an intergovernmental organization governed by international law, into a quasi-federal legal system that accords enforceable rights and obligations to legal persons, public and private, within EC territory. See A. Stone Sweet, The Judicial Construction of Europe (Oxford: Oxford University Press, 2004). ${ }^{61}$ For a brief analysis of the decisions and its implication see, J. Usher, European Community Law and National Law - The Irreversible Transfer (Unwin Hyman, 1981), 30 - 38.
} 
national law whether enacted before or after the Community norm. ${ }^{62}$ These two principles constitute the foundation of the EU legal order and are at the core of supranationalism as a concept.

Since the concept of supranationalism distinguishes the EU from other international organizations, it is pertinent to briefly explain the concept and its key precepts. According to Hay, supranational organizations are those that 'possess both independence from and power over their constituent states to a degree which suggests the emergence of a new federal hierarchy and which goes beyond traditional intergovernmental cooperation in the form of international organizations'. ${ }^{63}$ Weiler makes a distinction between normative and decisional supranationalism. Normative supranationalism according to him is "concerned with the relationships and hierarchy which exist between Community policies and legal measure on the one hand and competing policies and legal measures on the other'. ${ }^{64}$ In addition to the principles of direct effect and supremacy above, Weiler adds pre-emption ${ }^{65}$ as the three core attributes of the concept of normative supranationalism. Decisional supranationalism on the other hand, relates to the institutional framework and the decision-making processes through which the EU's policies and measures are initiated. ${ }^{66}$

Supranationalism is synonymous with the EU legal order due to the diminishing nature of intergovernmentalism (decision-making strictly by nation-states) in the practice of the organization as envisaged under customary international law. Can the AU, the premier regional

\footnotetext{
${ }^{62}$ By extension, the Court has the 'Kompetenz-Kompetenz" in the Community legal order. This principle does not imply a total rule of Community law over national law, but instead that each law (Community and national law) is supreme within its own sphere of competence.

63 P. Hay, 'International and Supranational Organizations: Some Problems of Conceptualization', (1965) 733 University of Illinois Law Forum', 733.

${ }^{64}$ J. H.H Weiler, 'The Community System: The Dual Character of Supranationalism' (1981) 1 Yearbook of European Law, 267, 271.

65 In Commission v Council (Case 22/70) [1971] ECR 263 pars 17 - 18 the ECJ highlighted the principle of preemption by ruling that each time the community, with a view to implementing common policy envisaged by the Treaty, adopts provisions laying down common rules, whatever form these may take, the Member States no longer have the right, acting individually or even collectively, to undertake obligations with third countries which affect those rules. As and when such common rules come into being, the Community alone is in a position to assume and carry out contractual obligation towards third countries affecting the whole sphere of application of the Community legal system. Writing on the scope of this principle see, M. Cremona, 'External Relations and External Competence: The Emergence of an Integrated Policy', in P. Craig \& G. De Burca (eds), The Evolution of EU Law (Oxford: OUP, 2011), 152.

${ }^{66} \mathrm{R}$. Leal-Arcas, 'Theories of Supranationalism in the EU', (2007) 8 Journal of Law and Society, 88, 98.
} 
${ }^{67}$ be considered a supranational organization at all? According to Weiler's theory, a legal inquiry into normative supranationalism of the AU will be "based on whether - in respect of specific areas of common interest and competence - the policies and laws of the AU" have direct effect in member states, and the laws of the organization are "superior to the laws of the member states and member states are pre-empted from enacting contradictory legislation". ${ }^{68}$ The above analysis points to an affirmative answer in the case of the EU. The AU on its part cannot be said to be a supranational organization. However, certain aspects of the norms and institutional practices emanating from the AU suggest that there is potential for certain aspects of the AU to assume supranational status.

The preamble of the Constitutive Act $(\mathrm{CA})^{69}$ of the AU conveys the intention of Member States to create a supranational organization thus:
"We, heads of States and Government of the member states .... [are] determined to take all necessary measures to strengthen our common institutions and provide them with the necessary powers and resources to enable them discharge their respective mandates effectively."

These common institutions are listed in article 5 of the CA and include the Assembly, Executive Council, Pan-African Parliament, Commission and the African Court of Justice. It also covers

\footnotetext{
${ }^{67}$ Article 3 of the Constitutive Act of the African Union outlines its objectives to include; The objectives of the Union shall be to: (a) achieve greater unity and solidarity between the African countries and the peoples of Africa; (b) defend the sovereignty, territorial integrity and independence of its member states; (c) accelerate the political and socio-economic integration of the continent; (d) promote and defend African common positions on issues of interest to the continent and its peoples; (e) encourage international co-operation, taking due account of the Charter of the United Nations and the Universal Declaration of Human Rights;(f) promote peace, security, and stability on the continent; (g) promote democratic principles and institutions, popular participation and good governance; (h) promote and protect human and peoples' rights in accordance with the African Charter on Human and Peoples' Rights and other relevant human rights instruments; (i) establish the necessary conditions which enable the continent to play its rightful role in the global economy and in international negotiations; (j) promote sustainable development at the economic, social and cultural levels as well as the integration of African economies; (k) promote co-operation in all fields of human activity to raise the living standards of African peoples; (I) co-ordinate and harmonise the policies between the existing and future Regional Economic Communities for the gradual attainment of the objectives of the Union; $(\mathrm{m})$ advance the development of the continent by promoting research in all fields, in particular in science and technology; $(\mathrm{n})$ work with relevant international partners in the eradication of preventable diseases and the promotion of good health on the continent.

${ }^{68}$ B. Fagbayibo, 'A supranational African Union? Gazing into the crystal ball', (2008) 41 De Jure, 493, 496.

${ }^{69}$ Constitutive Act of the African Union, 1 July 2000, available at:

https://www.refworld.org/docid/4937e0142.html last accessed 1 February 2019.
} 
other important bodies not listed in article 5 but form part of the AU such as the Peace and Security Council (PSC), the New Partnership for Africa's Development (NEPAD) and the African Peer Review Mechanism (APRM). These are institutions responsible for delivering on regional objectives ranging from security, human rights, globalization, socio-economic development, to political and democratic governance. These institutions also mirror the EU institutional hierarchy as the table below demonstrates.

Table 1: Overview of AU \& EU institutional hierarchy ${ }^{70}$

\begin{tabular}{|c|c|c|}
\hline $\begin{array}{l}\text { Role/Function } \\
\text { Institution }\end{array}$ & $\mathbf{A U}$ & $\mathbf{E U}$ \\
\hline $\begin{array}{l}\text { Provides overall strategy } \\
\text { and political direction }\end{array}$ & $\begin{array}{l}\text { The Assembly of Heads of State and } \\
\text { Government. Under Article } 6 \text { of the CA } \\
\text { the Assembly shall be constituted by } \\
\text { heads of State or Government and shall } \\
\text { be the supreme organ of the AU. } \\
\text { The functions of the Assembly shall be } \\
\text { to: (a) determine the common policies of } \\
\text { the Union; (b) receive, consider and take } \\
\text { decisions on reports and } \\
\text { recommendations from the other organs } \\
\text { of the Union; (c) consider requests for } \\
\text { Membership of the Union; (d) establish } \\
\text { any organ of the Union; (e) monitor the } \\
\text { implementation of policies and decisions } \\
\text { of the Union as well ensure compliance } \\
\text { by all Member States; (f) adopt the } \\
\text { budget of the Union; (g) give directives to } \\
\text { the Executive Council on the } \\
\text { management restoration of peace;(h) } \\
\text { appoint and terminate the appointment of } \\
\text { the judges of the Court of Justice; (i) } \\
\text { appoint the Chairman of the Commission } \\
\text { and his or her deputy or deputies and } \\
\text { Commissioners of the Commission. }\end{array}$ & $\begin{array}{l}\text { The European Council (of Heads } \\
\text { of Government/State) \& } \\
\text { Commission President. Article } \\
\text { 15(2) TEU specializes that the } \\
\text { European Council should be } \\
\text { made of the heads of State or } \\
\text { Government of the Member } \\
\text { States, the President of the } \\
\text { European Council and the } \\
\text { President of the Commission. } \\
\text { isepit plays an important political } \\
\text { role in shaping the future of the } \\
\text { EU. Amongst it functions } \\
\text { include: (a)It can examine any } \\
\text { matter within the competence of } \\
\text { the EU and that may be of } \\
\text { common interest; (b) It settles } \\
\text { sensitive matters and disputes } \\
\text { which the EU institutions are not } \\
\text { able to resolve, especially those } \\
\text { referred by the Council; } \\
\text { (c)Within the framework of the } \\
\text { EU foreign action, including the } \\
\text { CFSP, it defines principles and } \\
\text { guidelines; (d) It decides whether } \\
\text { a revision of the Treaties is } \\
\text { required under either the ordinary } \\
\text { revision procedure or the } \\
\text { simplified procedure; (e) It } \\
\text { appoints the President of the } \\
\text { European Council, selects the }\end{array}$ \\
\hline
\end{tabular}

\footnotetext{
${ }^{70}$ Adapted from A. Adamu \& A. M. Peter, 'Comparative Analysis of African Union and European Union: Challenges
} and Prospects', (2016) 3 Journal of Peace and Conflict Studies (IJPCS) 52. 


\begin{tabular}{|c|c|c|}
\hline & & $\begin{array}{l}\text { High Representative of the Union } \\
\text { for Foreign Affairs and Security } \\
\text { Policy (HR) and the President of } \\
\text { the European Commission; (f) It } \\
\text { determines the existence of a } \\
\text { serious and persistent breach by a } \\
\text { Member State of the European } \\
\text { Union's founding values (Article } \\
7(2) \text { TEU). }\end{array}$ \\
\hline $\begin{array}{l}\text { Coordination and } \\
\text { formulation of policies }\end{array}$ & $\begin{array}{l}\text { The Executive Council of the Ministries } \\
\text { of the Ministers of Foreign Affairs, or } \\
\text { other Ministers. The Executive Council } \\
\text { shall coordinate and take decisions on } \\
\text { policies in areas of common interest to } \\
\text { the Member States, including the } \\
\text { following: (a) foreign trade; (b) energy, } \\
\text { industry and mineral resources; (c) food, } \\
\text { agricultural and animal resources, } \\
\text { livestock production and forestry; (d) } \\
\text { water resources and irrigation; (e) } \\
\text { environmental protection, humanitarian } \\
\text { action and disaster response and relief; (f) } \\
\text { transport and communications; (g) } \\
\text { insurance; (h) education, culture, health } \\
\text { and human resources development; (i) } \\
\text { science and technology; (j) nationality, } \\
\text { residency and immigration matters; (k) } \\
\text { social security, including the formulation } \\
\text { of mother and child care policies, as well } \\
\text { as policies relating to the disabled and the } \\
\text { handicapped; (l) establishment of a } \\
\text { system of African awards, medals and } \\
\text { prizes. The Executive Council shall be } \\
\text { responsible to the Assembly. It shall } \\
\text { consider issues referred to it and monitor } \\
\text { the implementation of policies formulated } \\
\text { by the Assembly. }\end{array}$ & $\begin{array}{l}\text { The General Affairs Council, or } \\
\text { the Council of the EU. The } \\
\text { Council together with the } \\
\text { European Parliament is the main } \\
\text { legislative institution of the EU } \\
\text { and defines and implements the } \\
\text { EU's Common Foreign and } \\
\text { Security Policy (CFSP). It } \\
\text { represents the national interests } \\
\text { of each EU Member State and is } \\
\text { an intergovernmental body. } \\
\text { Under Article 121 TFEU the } \\
\text { Council is mandated to co- } \\
\text { ordinate economic policies of EU } \\
\text { Member States. It also organises } \\
\text { co-operation between Member } \\
\text { States in respect of employment } \\
\text { policies (Article 148(2)) TFEU), } \\
\text { (the Area of freedom, security } \\
\text { and justice (AFSJ) Article } 74 \\
\text { TFEU) and in respect of } \\
\text { operational police co-operation } \\
\text { (Article 87(3) TFEU). The } \\
\text { Council rarely exercises } \\
\text { executive powers. }{ }^{71} \quad\end{array}$ \\
\hline $\begin{array}{l}\text { The secretariat }- \text { the } \\
\text { cabinet and the } \\
\text { bureaucracy }\end{array}$ & $\begin{array}{l}\text { Under Article } 20 \text { of the CA the } \\
\text { Commission is composed of the } \\
\text { Chairman, his or her deputy or deputies } \\
\text { and the Commissioners, they shall be } \\
\text { assisted by the necessary staff for the } \\
\text { smooth functioning of the Commission. }\end{array}$ & $\begin{array}{l}\text { The Commission of the EU; } \\
\text { headed by an appointed } \\
\text { President. The Commission } \\
\text { represents the interests of the EU. } \\
\text { The Commission exercises many } \\
\text { functions, the most important is }\end{array}$ \\
\hline
\end{tabular}

\footnotetext{
${ }^{71}$ The Council can exercise executive powers in the cases provided for in Articles 24 and 26 TFEU relating to the CFSP.
} 


\begin{tabular}{|c|c|c|}
\hline & $\begin{array}{l}\text { The structure, function and regulations of } \\
\text { the Commission is to be determined by } \\
\text { the Assembly. }\end{array}$ & $\begin{array}{l}\text { to "promote the general interest } \\
\text { of the Union and take appropriate } \\
\text { initiatives to that end" (Article } 17 \\
\text { TEU). The Commission is the } \\
\text { guardian of the Treaties; } \\
\text { initiator of EU legislation; } \\
\text { executive arm of the EU; and } \\
\text { is the representative of the EU in } \\
\text { the international arena, except } \\
\text { with regard to the CFSP, and in } \\
\text { other cases provided for in the } \\
\text { Treaties. }\end{array}$ \\
\hline Legislature & $\begin{array}{l}\text { Pan - African Parliament (PAP) is } \\
\text { presently an advisory body and lacks any } \\
\text { form of legislative power. }\end{array}$ & $\begin{array}{l}\text { European Parliament (EP). The } \\
\text { ToL describes the EP as } \\
\text { exercising legislative powers } \\
\text { jointly with the Council in certain } \\
\text { areas. (See Article } 16 \text { TEU) The } \\
\text { EP may jointly legislate with the } \\
\text { Council in matters regarding } \\
\text { measures relating to frontier } \\
\text { controls, asylum, immigration, } \\
\text { judicial co-operation in criminal } \\
\text { matters, minimum rules for the } \\
\text { definition of, and penalties in, the } \\
\text { areas of serious crime, incentive } \\
\text { measures for crime prevention, } \\
\text { Eurojust, police co-operation, } \\
\text { Europol and civil protection. The } \\
\text { EP exercises political control } \\
\text { over some EU institutions, in } \\
\text { particular by being involved in } \\
\text { the election of the President of } \\
\text { the Commission, the members of } \\
\text { the Commission and the HR. }{ }^{72} \text { It } \\
\text { also enjoys supervisory powers } \\
\text { over other EU institutions. }\end{array}$ \\
\hline Judicial Review & African Court of Justice (ACJ) & $\begin{array}{l}\text { European Court of Justice (ECJ); } \\
\text { apex court of the EU }\end{array}$ \\
\hline
\end{tabular}

72 Kaczorowska-Ireland, note 41 above, 67. 
It is apparent that the functions of $\mathrm{AU}$ institutions reveal an intention on the part of the drafters of the CA to confer some degree of supranationalism on these institutions. For instance, the Assembly, in terms of article 9 of the CA, has the powers to determine, monitor and ensure compliance with common policies. Similarly, the Executive Council may coordinate and take decisions on policies in areas such as foreign trade, immigration matters, transport and communication, education, health and agriculture. ${ }^{73}$

Another example is the General Affairs Section ${ }^{74}$ of the proposed African Court of Justice and Human Rights (ACJHR) $)^{75}$ which will exercise jurisdiction over matters relating to interpretation of the CA, disputes between states, and acts and functions of the organs of the AU. ${ }^{76}$ Furthermore, the General Section of the court may constitute itself into a special chamber for the purpose of hearing matters relating to trade, economics and the environment. ${ }^{77}$ The court does not possess jurisdiction over non-ratifying AU states. ${ }^{78}$ However, these states may appear by special dispensation from the AU Assembly ${ }^{79}$ or may on notice of the Court Registrar, intervene in a case pertaining to the interpretation of the CA. ${ }^{80}$

Another supranational feature of the CA that is worthy of mention is the AU's right of intervention in member States. The CA introduced the exclusive right of the AU to intervene under the following conditions, war crimes, genocide, crime against humanity and, a serious threat to legitimate order. ${ }^{81}$ Unlike the Organization of African Unity (OAU) Charter, the CA circumscribed the provision on sovereignty and the territorial integrity of Member States which was the zeitgeist of the newly independent African states that formed the organization.

\footnotetext{
${ }^{73} \mathrm{AU}$ CA article $23(2)$.

74 The Statute of the proposed African Court of Justice and Human Rights provides two sections of the Court: the General Section composed of 7 judges and the Human Rights Section composed of 5 judges; art 15, Protocol on the African Court of Justice and Human Rights and Annexed Statute 2006. The Human Rights Section will be competent to entertain matters relating to violations of human rights: art. 16(2).

${ }^{75}$ It is expected that the African Court of Justice will be merged with the African Court of Justice and Human Rights. The protocol establishing the ACJHR is yet to be ratified by all state parties to the African Charter. By January 2019, only 30 (namely Algeria, Benin, Burkina Faso, Burundi, Cameroon, Chad, Côte d'Ivoire, Comoros, Congo, Gabon, Gambia, Ghana, Kenya, Libya, Lesotho, Mali, Malawi, Mozambique, Mauritania, Mauritius, Nigeria, Niger, Rwanda, Sahrawi Arab Democratic Republic, South Africa, Senegal, Tanzania, Togo, Tunisia and Uganda) out of 55 AU member States had ratified the African Court Protocol.

${ }^{76}$ Article 30.

77 Article 18(1).

78 Article 30(3).

${ }^{79}$ Article 30(2).

${ }^{80}$ Article 60.

${ }^{81}$ Article 4(h).
} 
However, it is evident that the designated supranational institutions are some way short of exercising consummate normative supranationalism. ${ }^{82}$ It appears that decision-making powers are firmly placed in the hands of organs which are entirely composed of representatives of national governments. The AU and most RECs in Africa majorly rely on the Assembly of Heads of States and the Council of Ministers to make policy and legal decisions.

Decisional supranationalism involves the autonomy of intergovernmental institutions to formulate policies and to make key decisions. ${ }^{83}$ Central to this autonomy is the majority voting system. Majority voting ensures that the voting requirement of a community is satisfied, and that Member States are bound by a decision whether or not they support it. ${ }^{84}$ In this wise, the AU appears to possess some element of decisional supranationalism. ${ }^{85}$ Article 7 of the CA provides that the Assembly may ratify decisions by "consensus or failing which, by which a two-thirds majority of the member states of the Union, apart from procedural matters which require a simple majority".

According to Weiler's theory of supranationalism, supranational status may only accrue to international organizations that possess both decisional and normative supranationalism within the institutional framework. Thus, the absence of normative supranationalism within the institutional framework of the AU would suggest that the AU qualifies mainly as an intergovernmental organization. However, the AU possesses the potential to gradually evolve into a supranational organization. More importantly, supranationalism is not a static or fixed concept. It may be limited to specific areas of an organization's activities; in other words, supranationalism and intergovernmentalism may coexist within the same organization, but on different issues or subject matters. ${ }^{86}$

The relationship between supranationalism and sovereignty cannot be overstated. As Hay has argued, 'with few exceptions... the criteria for loss of sovereignty coincide with those which much of the literature regards as the elements of supranationalism. Thus the concept of transfer of sovereignty may be the legal-analytical counterpart of the political-descriptive notion of

\footnotetext{
${ }^{82}$ For example, the Pan-African Parliament merely exercises consultative and advisory powers and its members are not directly elected by citizens of the member states. In accordance with article 4(2) of the CA, the PAP is presently comprised of 5 nominees each from member states which makes up 265 members in total. See, https://au.int/en/organs/pap (accessed 23/06/20)

${ }^{83}$ Weiler, note 64 above, 281.

${ }^{84}$ Fagbayibo, note 68 above, 498.

${ }^{85} \mathrm{Ibid}$.

${ }^{86}$ Oppong, note 5 above, 34 .
} 
supranationalism'. ${ }^{87}$ It then becomes apparent that African states still operate with a lot of caution in creating supranational institutions. Instead they have opted to guard their sovereignty six decades after the OAU was established. The unwillingness to vest regional institutions with comprehensive supranational powers and to create the necessary national frameworks to implement community laws and policies remains the bane of regional integration in Africa. Udombana places that responsibility squarely on the shoulders of African leaders when he argued thus:

"African leaders lack the certitude to face the challenges of integration. Integration requires that each constituent party have clearly defined national plans and strategies to achieve economic development. Like a child in a toyshop, most leaders in Africa do not know which way to look. They have been unable to make the changes that will sustain growth and development. Others are not prepared to subordinate immediate national plans to long-term economic regional goals or to cede essential elements of sovereignty to regional institutions." $" 88$

While the above commentary is true of integration in Africa, the historiography of the EU demonstrates that clothing institutions with sovereign attributes is a delicate process. It demands cautious and calculated steps, tactful negotiations, constant assurances and compromises, and the skilful management of national egoisms. ${ }^{89}$ It is therefore obvious to state that the AU in its present form may find it challenging to achieve its common objectives. To balance the intergovernmental overweight of the AU, the Council and the PAP, should be empowered to facilitate the pace of integration by using the sanction power to ensure that member States comply with integration policies. It is also crucial that the PAP is vested with legislative powers, at least over issues relating to human rights, trade, the AU budget, and democratic supervision over the AU commission and appointment of judges. ${ }^{90}$

\footnotetext{
${ }^{87}$ Hay, note 63 above, 69.

${ }^{88}$ N. Udombana, 'A harmony or cacophony? The music of integration in the African Union Treaty and the New Partnership for Africa's Development' (2002) Indiana International and Comparative Law Review, 202.

${ }^{89}$ Fagbayibo, note 68 above, 500.

${ }^{90}$ To further strengthen the parliament in this regard, national and sub-regional parliaments should set up ad hoc committees to constantly liaise with the PAP with a view to presenting common policies.
} 


\section{SOME SUGGESTIONS FOR MOVING AU LAW FORWARD}

In order to achieve the supranational ambitions of the AU, concerted effort would need to be geared towards improving the AU's supranational credentials. The first step in improving the AU legal system is to harmonize the varying legal standards across the continent. This would in turn ensure the easy and uniform implementation of laws and decisions across the region. As mentioned above, institutions such as OHADA are fundamental to ensuring common laws across the region because they provide tested templates for the advancement of the integration agenda.

Incidental to strengthening the $\mathrm{AU}$ as a legal system is the proper definition of the relationship between the AU and the African Economic Community, the AU and (RECs) ${ }^{91}$, and the relationship between Community law and national laws. This complex web of legal orders under the umbrella of the AU, is aptly captured as the problem of 'properly structuring and managing, within well-defined legal frameworks, vertical, horizontal and vertico-horizontal relations among states, legal systems, laws and institutions. ${ }^{92}$ It is important to rationalize the relationship between the various sub-regional communities, eliminating the problem of multiple memberships of the communities and putting the path to the formation of the AEC on solid legal foundations by enacting a clear legal framework to regulate relations between all levels. The recently signed African Continental Free Trade Agreement (AFCFTA) ${ }^{93}$ that aims to bring together markets of 44 countries is a step towards achieving the kind of market integration which the Abuja treaty envisages. It is also important that AU Member States show some seriousness in achieving the African Economic Community by the implementation of the AFCFTA. ${ }^{94}$

\footnotetext{
${ }^{91}$ The AU recognizes eight RECs as the foundational constituents of the African Economic Community (AEC) upon which a region-wide common market. They are Arab Maghreb Union (AMU), the East African Community (EAC), the Economic Community of Central African States (ECCAS), the Economic Community of West African States (ECOWAS), the Common Market for Eastern and Southern Africa (COMESA), the Community of Sahel-Saharan States (CENSAD), the South African Development Community (SADC), and the Intergovernmental Authority for Development (IGAD).

${ }^{92}$ Oppong, note 5 above, 31.

${ }_{93}$ Agreement Establishing the African Continental Free Trade Area (AFCFTA), entered into force on 30 May 2019. See text at: https://au.int/en/treaties/agreement-establishing-african-continental-free-trade-area (accessed 12 February 2020). This new continent-wide regime is poised to ensure increased intra-African foreign investment. The AFCFTA is expected to build on the considerable successes already achieved by Africa's regional economic communities (RECs). However, it fails to clarify how the overlapping regimes will be reconciled and harmonised. Nevertheless, the agreement is laudable for its quest to facilitate intra-African trade, foster regional value chains that can facilitate integration into the global economy, and energize industrialization, competitiveness and innovation.

${ }^{94}$ Writing on the crucial steps towards implementation of the AFCFTA see, F. Kamusiime, 'How to Implement the AFCFTA', available at http://www.afronomicslaw.org/2019/01/28/how-to-implement-the-afcfta/ last accessed 31 January 2019.
} 
Another important aspect towards developing AU law is to encourage Member States to enact legislation implementing respective community treaties which they are parties to. This should be built upon detailed national studies on any potential conflicts between community law and national laws. ${ }^{95}$ This would enable Member States identify and resolve differences between national laws and community law to ensure compliance. The resultant effect of a considered approach to synergizing domestic law and community law is that it will ensure collaboration between national institutions and their regional counterparts.

The steps above should be followed by concrete community and national measures aimed at boosting the interest in community law by supporting constituencies. In this regard, constituencies such as lawyers, judges, law enforcement agencies and training institutions, corporations and small-scale businesses should be at the heart of drive to normalize community law. The integration of AU law into national education curricula and other forms of educational campaigns cannot be underestimated. These constituencies serve the purpose of maintaining the momentum necessary for the societal aspects of integration and this is inevitable for the development of AU law.

The important role of a judicial organ in the sustenance of a legal system cannot be overstated. African courts have always adopted a teleological approach to interpreting community laws, sometimes with very undesirable consequences. ${ }^{96}$ However, a liberal and innovative approach to interpreting provisions of the constitutive instrument of the $\mathrm{AU}$ is necessary in moving towards developing concepts and principles which are essential for the furtherance and solidification of the integration process. For instance, in Actions Pour La Protection Des Droits De L'homme (APDH) v. Cote d'Ivoire ${ }^{97}$ the African Court on Human and Peoples Rights (ACHPR) in a ground-breaking decision defined the meaning of a human rights

\footnotetext{
${ }^{95} \mathrm{An}$ instance of such studying of community law is the National Steering Committee established by the Nigerian government in 2018 to study the impact of the AFCFTA and advice on Nigeria's readiness vis-a-via the treaty. The report of the Committee is due in early 2019. See, 'Nigeria's study on AFCFTA ready next January' available athttps://www.theeastafrican.co.ke/news/africa/Nigeria-study-on-AfCFTA-ready-in-January/4552902-4903656hk4p8yz/index.html last accessed 31 January 2019.

${ }^{96} \mathrm{Attempts}$ by sub-regional courts to purposively interpret treaties and expand their original jurisdictions into human rights have been met with resistance and retaliation from member States. After several judgments ruling against Zimbabwe in the Mike Campbell case, the SADC Tribunal was suspended in 2010. It is yet to be reconstituted. See, L. Nathan, 'The Disbounding of the SADC Tribunal: A Cautionary Tale', (2013) 35 Human Rights Quarterly 870; K.J Alter, J.T Gathii, L.R Helfer, 'Backlash against International Courts in West, East and Southern Africa: Causes and Consequences', (2016) 27 European Journal of International Law 293.

${ }^{97}$ App. No. 001/2014.
} 
instrument. It established that the ECOWAS Protocol on Democracy and Good Governance $(2001)^{98}$ which is a sub-regional law is tantamount to a human rights instrument, because it intended to implement a number of civil and political rights such as the right to vote and the right to participate freely in elections as enshrined in the African Charter on Human and Peoples Rights. This laudable decision of the ACHPR is exemplary and underscores the potential of regional courts to develop community norms. The larger effect of the decision is the entrenchment of protocols of RECs as enforceable sources of AU community law.

The planned African Court of Justice and Human Rights is long overdue to fill this important void. An effective continental level regional court of its stature is important as it has the potential to fast-track closer integration by making judicial pronouncements on issues at the heart of the objectives of the AU. It will be expected to decide issues such as the question on whether the Member States obligation to adhere to the principles of the AU include the ratification of key protocols, multi-level governance within the AU, the role of RECs within the integration framework, and the roles of municipal court sand parliaments in the integration process. ${ }^{99}$ It is noteworthy that the availability of an effective enforcement mechanism to ensure the strict implementation of the courts decisions will be a necessary compliment to the establishment of the Court. ${ }^{100}$

\section{CONCLUSION}

This chapter has explored the emergent AU law through the lenses of comparative law. The EU represents the most advanced supranational body that has evolved beyond state legal order and it is thus the most relevant comparator. The chapter recognises that while the AU's supranational credential is still at an evolutionary stage, there are parallels with the EU and through a comparative analysis, guidance could be found for the progression of AU law. Comparative law methodology provides the most useful approach to understanding this phenomenon because of its relatively well-established parameters and also because of its adaptability to new developments.

\footnotetext{
98 Protocol A/SP1/12/01 on Democracy and Good Governance available athttp://www.internationaldemocracywatch.org/index.php/economic-community-of-west-african-states-treatiesand-protocols/350-protocol-on-democracy-and-good-governance-2001.

${ }^{99}$ Fagbayibo, note 68 above, 502.

${ }^{100}$ Some authors have suggested that a political body such as the AU Council of Ministers should have the power to monitor compliance with the court's orders. See,G.Musila 'United States of Africa: Positioning the Pan African Parliament and the Court in the Political Union Debate (2007) ISS Paper 142, 5-6.
} 
It is also appropriate because of its ability to question and interrogate traditional premises in the face of new developments. Despite the criticism that comparative law has a Eurocentric origin and influence, it has evolved to accommodate a plurality of legal systems. It has thus become an important methodology for the understanding of new legal systems such as the AU law.

In relation to the EU legal system, the chapter finds that comparative methodology has been used to facilitate the unification of different national legal orders in EU Member States. The methodology thus helped in shaping the emergence of new supranational laws and norms. Furthermore, comparative law has been used in the approximation and harmonisation of laws and standards. In addition, the Court of Justice of the EU has also employed the comparative methodology extensively in the interpretation of EU law. These three ways in which comparative law has been successfully employed in the EU is instructive for the AU legal order because of the diversity of traditions that it has to contend with. It is instructive to note that regional organizations such as the Organization for the Harmonisation of Business Laws in Africa (OHADA) are in the lead in the attempt to address the diversity of legal traditions in commercial law in parts of Africa.

While it is conceded that the supranationalism status of the AU is debatable, and at an early stage, the AU Constitutive Act conceived the AU as a supranational body. The institutions created under the Constitutive Act bear some resemblance in form to that of the EU. It is thus arguable that there is a legal basis for evolving the AU and its legal order to a full-fledged supranational system. In that connection, from the comparative analysis, the chapter makes some suggestions for moving AU law forward. These include improving harmonisation and integration of norms, better delineation of the role and responsibility of the diversity of institutions in the continent in relation to the integration agenda, facilitating Member State implementation of community law and strengthening the role of the AU judicial system. 